\title{
Ketahanan Sosial Berbasis Kelompok Peduli Lingkungan dalam Menghadapi Pandemi COVID-19: Studi pada Gerakan Bersih Kecamatan Anggana
}

\author{
Aldita Cindy Arfidiandra ${ }^{1}$, Riana Rahmaningrum² ${ }^{2}$, Wazirul Luthfi ${ }^{3}$
}

\begin{abstract}
Abstrak
Memasuki tahun 2020, dunia dihadapkan dengan kemunculan wabah infeksi Coronavirus Disease 2019 (COVID-19). Kemunculan wabah tersebut berdampak pada aspek kehidupan masyarakat yang mendorong adanya perubahan. Hal ini menjadikan institusi sosial seperti Gerakan Bersih Kecamatan Anggana (GBKA) berupaya menghadapi perubahan tersebut. Tujuan penelitian ini adalah mendeskripsikan upaya GBKA mewujudkan ketahanan sosial melalui cara dan pendekatan kelompok dalam menghadapi kondisi pandemi COVID-19. Metode penelitian yang digunakan adalah kualitatif dengan pendekatan deskriptif. Penelitian ini menemukan bahwa unsur "Betulungan" atau tolong menolong sebagai nilai kearifan lokal yang dimiliki masyarakat berperan penting dalam dinamika kelompok untuk mewujudkan ketahanan sosial. "Betulungan" menjadi potensi dalam rangkaian proses adaptasi kelompok guna mempertahankan eksistensi GBKA di tengah pandemi COVID-19.
\end{abstract}

Kata kunci: ketahanan sosial; kelompok sosial; adaptasi; kerentanan

\begin{abstract}
At the beginning of 2020, the world is overcoming an outbreak of Coronavirus Disease 2019 or known as COVID-19. The outbreak has disrupted community's lives which leads to social change. In fact, like the roles of another social institution, GBKA tries to overcome this social changes. The study aims to describe GBKA's efforts to achieve social resilience through a community approach in this pandemic COVID-19 situation. The research uses descriptive qualitative approach. This study found that the element of "Betulungan" or known as mutual assistance as the value of local wisdom owned by the community has an important role of community to achieve social resilience. "Betulungan" is a capital in a process of adaptation of community group in order to maintain the sustainability of the group in this COVID-19 pandemic situation.
\end{abstract}

Keywords: social resilience; community group; adaptive capacity; vulnerabilities

\section{Pendahuluan}

Pada tahun 2020 awal, dunia dihadapkan dengan adanya wabah infeksi Coronavirus Disease 2019 atau dikenal dengan sebutan COVID-19. Bencana menurut Carter dalam Kodoatie dan Roestam, dikategorikan atas empat jenis yaitu 1) bencana alam seperti erupsi gunung berapi, gempa bumi, dan tsunami, 2) bencana biologis seperti epidemi, penyakit tanaman, kelaparan, pes dan kepunahan spesies, 3 ) bencana antropogenik yang disebabkan oleh teknologi, dan 4) bencana struktural yang disebabkan oleh pengambilan kebijakan untuk mendorong terjadinya konflik, perang antar suku, nuklir, dan terorisme (Kodoatie \& Roestam, 2006). Berdasarkan klasifikasi bencana tersebut, maka diketahui bahwa
COVID-19 merupakan kategori bencana biologis dengan status pandemi. Menurut WHO (World Health Organization) pandemi adalah epidemi yang terjadi di seluruh dunia atau pada daerah yang sangat luas, yang melintasi perbatasan beberapa negara, dan biasanya mempengaruhi banyak orang (Hadi, 2020). Merebaknya infeksi COVID-19 dalam kurun waktu yang singkat telah berdampak pada kondisi sosial ekonomi negara-negara di dunia. Dampak sosial dari adanya bencana mengakibatkan rusaknya sistem sosial dan norma sosial, hilangnya lapangan pekerjaan, serta ketidakstabilan politik nasional dan internasional (Blaikie, 2002).

Dampak pandemi COVID-19 di Indonesia dirasakan oleh hampir seluruh kelompok masyarakat. Kebijakan untuk menutup

\footnotetext{
${ }^{1}$ PT Pertamina Hulu Mahakam Lapangan CPU (email korespondensi: acindya.arf@gmail.com)

${ }^{2}$ PT Pertamina Hulu Mahakam Lapangan CPU (email: riana.rahmaningrum@mitrakerjapertamina.com)

${ }^{3}$ PT Pertamina Hulu Mahakam Lapangan CPU (email: wazirul.luthfi@pertamina.com)
} 
Aldita Cindy Arfidiandra, Riana Rahmaningrum, Wazirul Luthfi - Ketahanan Sosial Berbasis Kelompok Peduli Lingkungan dalam Menghadapi Pandemi COVID-19: Studi pada Gerakan Bersih Kecamatan Anggana

sementara ruang usaha dan pembatasan ruang gerak merupakan bentuk respon atas himbauan pemerintah yang bertujuan memutus rantai penyebaran COVID-19. Tetapi pada pelaksanaannya pembatasan aktivitas menimbulkan dampak terganggunya ketahanan sosial masyarakat dalam menghadapi kondisi ini. Ketahanan sosial merupakan daya tahan suatu kelompok masyarakat dalam menghadapi hantaman perubahan. Dalam dinamikanya kelompok melakukan adaptasi selama masa transisi dengan bertahan, menerima atau menolak perubahan tersebut. Terbatasnya ruang gerak masyarakat selama masa pandemi COVID-19 ini telah memberikan dampak multidimensi pada sektor kehidupan masyarakat.

Tulisan ini mendeskripsikan bagaimana ketahanan sosial kelompok Gerakan Bersih Kecamatan Anggana (GBKA) dalam menghadapi masa pandemi COVID-19. GBKA merupakan kelompok lokal yang bergerak dalam bidang pengelolaan sampah dan edukasi Pola Hidup Bersih dan Sehat (PHBS). Kegiatan tersebut diimplementasikan sebagai bagian dari Program Betulungan Beberseh Kampong sebuah program dampingan PT Pertamina Hulu Mahakam yang dilaksanakan di Kecamatan Anggana, Kabupaten Kutai Kertanegara, Kalimantan Timur. Sebagai kelompok yang memiliki lingkup kegiatan di tingkat kecamatan, keberadaan GBKA diharapkan dapat berperan aktif dalam upaya meningkatkan perilaku hidup bersih dan sehat dalam masyarakat, khususnya dalam menghadapi pandemi COVID-19. Keberadaan lembaga sosial lokal, seperti GBKA, dalam kehidupan masyarakat sampai saat ini masih dipandang sebagai sistem yang dapat mengatur keseimbangan bagi terciptanya harmonisasi kehidupan sosial masyarakat (Padmiati, 2013).

Kelompok GBKA diinisiasi oleh PT Pertamina Hulu Mahakam melalui Program Betulungan Beberseh Kampong pada tahun 2017 dengan nama Gerakan Sei Meriam Bersih. Pada tahun 2018, Gerakan Sei Meriam Bersih resmi berubah menjadi Gerakan Bersih Kecamatan Anggana. Perubahan nama tersebut dilakukan sebagai upaya untuk melibatkan desa-desa lainnya di Kecamatan Anggana dalam implementasi program. Sasaran Program Betulungan Beberseh Kampong merupakan ibu-ibu rumah tangga yang tidak memiliki pekerjaan utama. Meskipun begitu, dalam pelaksanaannya warga lainnya yang bersedia berkontribusi aktif dan konsisten dapat bergabung menjadi nasabah kelompok bank sampah unit GBKA. Hingga saat ini, sebagian besar nasabah bank sampah yang telah bergabung merupakan ibu-ibu rumah tangga. Pada pelaksanaannya, GBKA didampingi oleh PT Pertamina Hulu Mahakam bekerja sama dengan Ecco Walibar - sebuah LSM yang bergerak dalam bidang pengelolaan sampah. Fokus dari GBKA adalah isu lingkungan dan juga kesehatan. GBKA mengangkat isu krisis sampah yang merupakan sebuah permasalahan yang belum tertangani di Kecamatan Anggana, serta edukasi mengenai Perilaku Hidup Bersih dan Sehat (PHBS). Dengan demikian, kegiatan utama kelompok GBKA adalah mensosialisasikan pentingnya pengelolaan sampah rumah tangga serta menginisiasi pembentukan kelompok bank sampah unit di desa-desa terutama area sekitar operasi PT Pertamina Hulu Mahakam.

\section{Kerangka Teori}

Tulisan ini menjelaskan mengenai kondisi kerentanan anggota GBKA - yang berkaitan dengan ketahanan sosial kelompok - ditinjau melalui cara kelompok bertahan dengan menerima dan beradaptasi atau sebaliknya menolak perubahan. Upaya mengukur kerentanan sosial (social vulnerability) berangkat dari pemahaman bahwa kerentanan sosial merujuk pada penerimaan terhadap terpaan suatu bahaya atau adanya kondisi stres di tingkat kelompok atau perorangan akibat terpaan suatu bencana yang dipengaruhi oleh faktor akses terhadap sumber daya alam dan diversitas sumber pendapatan (Wahyono, 2016). Kerentanan yang dialami anggota kelompok GBKA pada masa pandemi COVID-19 perlu dijelaskan untuk dapat melihat bentuk atau jenis kerentanan yang dialami. Hal tersebut selanjutnya mendasari kerangka pikir dalam menyusun upaya strategis menghadapi kerentanan. Sehingga kemudian, selaras dengan kebutuhan identifikasi kerentanan dengan tujuan untuk menentukan indikator efektif, dalam rangka mempromosikan tindakan perbaikan dengan strategi bertahan dan memfasilitasi adaptasi yang dilakukan (Wahyono, 2016).

Kapasitas adaptasi diartikan sebagai sebuah sistem untuk menyerap gangguan dan melakukan reorganisasi pada saat mengalami perubahan sehingga dapat mempertahankan fungsi, struktur, identitas, dan masukan atau dengan kata lain tetap tidak berubah dalam 
dasar daya tarik (Gallopin, 2006). Kemampuan beradaptasi ini dipicu oleh adanya kesadaran kolektif di dalam kelompok dalam merespon perubahan atau kerentanan yang dialami. Proses adaptasi lebih dapat terlihat pada komunitas daripada individu karena berkaitan erat dengan aset sistem mata pencaharian, seperti modal sosial, modal alam, modal manusia, dan modal fisik, baik dari komunitas maupun masyarakat (Wahyono, 2016). Berdasarkan definisi konseptual diatas, maka kemampuan adaptasi dapat diartikan sebagai unsur atau kemampuan yang harus dimiliki dalam suatu kelompok untuk mewujudkan ketahanan sosial.

Ketahanan sosial kelompok GBKA dalam menghadapi kondisi pandemi COVID-19 ini diketahui melalui identifikasi atas kerentanan yang dialami dan kemampuan beradaptasi kelompok dalam menghadapi perubahan. Ketahanan sosial suatu komunitas sering dikaitkan dengan kemampuannya dalam mengatasi berbagai risiko perubahan sosial, ekonomi, dan politik yang mengelilinginya (Betke, 2002). Ketahanan suatu kelompok sosial dalam menghadapi adanya perubahan menurut Djojodiguno dapat dilihat dari keberfungsian kelompok tersebut selama menghadapi masa transisi. Tidak sedikit kasus ketidakberfungsian suatu lembaga sosial ketika dihadapkan oleh adanya perubahan yang terjadi secara tibatiba. Lembaga sosial dalam konteks ketahanan sosial semakin menjadi bermakna penting dan strategis dalam berbagai dimensi kehidupan sosial masyarakat (Sugiyanto, 2002). Tidak adanya kemampuan beradaptasi dalam menghadapi kondisi tertentu bisa menjadi faktor kegagalan fungsi suatu lembaga. Komunitas dapat dikatakan memiliki ketahanan sosial apabila; 1) mampu secara efektif melindungi anggotanya termasuk individu dan keluarga yang rentan dari gelombang perubahan sosial yang mempengaruhinya; 2) mampu melakukan investasi sosial dalam jaringan sosial yang menguntungkan dan; 3) mampu mengembangkan mekanisme kerja yang efektif dalam mengelola konflik dan kekerasan (Betke, 2002).

Peran lembaga sosial dalam ketahanan sosial dapat ditinjau dari kemampuan komunitas atau lembaga tersebut dalam memfungsikan modal sosial sehingga mampu melindungi anggotanya secara efektif, termasuk individu dan keluarga yang rentan terhadap gelombang perubahan sosial serta mampu melakukan investasi sosial dalam jaringan yang menguntungkan dan mengembangkan mekanisme efektif dalam pengelolaan konflik dan kekerasan (Padmiati, 2013). Unsur dalam modal sosial berperan signifikan terhadap terwujudnya ketahanan sosial. Lembaga sosial berfungsi sebagai media untuk memfungsikan modal sosial yang telah dimiliki masyarakat. Dikatakan bahwa wujud nyata dari modal sosial adalah kelompok sosial yang dibentuk oleh komuniti itu sendiri (Padmiati, 2013). Adanya norma, jaringan dan kepercayaan sebagai unsur modal sosial itulah yang menggerakkan masyarakat untuk melakukan tindakan kolektif. Ketiga unsur tersebut berfungsi sebagai alat pemersatu tujuan dan penentu tindakan kolektif untuk mewujudkannya.

\section{Metode Penelitian}

Kajian mengenai ketahanan sosial kelompok GBKA dalam menghadapi masa pandemi COVID-19 ini dilakukan melalui metode kualitatif dengan pendekatan deskriptif. Penelitian kualitatif mampu menggali informasi secara mendalam, serta terbuka terhadap segala pendapat dan pernyataan, tidak semata pada jawaban "ya' dan "tidak" (McCarthy, 2006). Pada konteks kajian ini, identifikasi kerentanan anggota kelompok GBKA dan identifikasi upaya kelompok menghadapi pandemi COVID-19 selaras dengan kerangka berpikir penelitian kualitatif. Artinya, ketahanan sosial kelompok GBKA akan dilihat melalui upaya-upaya yang ditempuh sebagai lembaga sosial terhadap kerentanan yang dihadapi masyarakat dalam kondisi pandemi COVID-19.

Teknik pengambilan data dalam penelitian ini adalah pengamatan, wawancara terhadap pihak-pihak yang terlibat dalam keberlangsungan kelompok GBKA, studi literatur dan dokumentasi. Informan yang diwawancarai adalah 10 anggota bank sampah dan 2 pengurus GBKA. Pada proses pengambilan data, peneliti menjadi pengamat sekaligus pelaku yang terlibat dalam pelaksanaan kegiatan. Studi literatur dilakukan dengan menelaah penelitianpenelitian sebelumnya yang berkaitan dengan ketahanan sosial suatu lembaga, dan indikator kerentanan suatu kelompok masyarakat. Lokasi penelitian adalah di Kecamatan Anggana, Kabupaten Kutai Kertanegara, Kalimantan Timur sebagaimana wilayah program tanggung 
Aldita Cindy Arfidiandra, Riana Rahmaningrum, Wazirul Luthfi - Ketahanan Sosial Berbasis Kelompok Peduli Lingkungan dalam Menghadapi Pandemi COVID-19: Studi pada Gerakan Bersih Kecamatan Anggana

jawab sosial perusahaan yang dilakukan oleh PT Pertamina Hulu Mahakam dalam Program Betulungan Beberseh Kampong.

\section{Hasil}

\section{Kerentanan Kelompok GBKA}

Dampak bencana pandemi COVID-19 di Indonesia bersifat multidimensional dan tersebar hampir di seluruh wilayah provinsi, dan tidak hanya terbatas pada bidang kesehatan, dimana telah ditetapkan status bencana nasional bidang kesehatan, namun juga pada bidang lainnya, terutama ekonomi dan sosial budaya (Hadi, 2020). Pemerintah merespon pandemi COVID-19 ini dengan menyusun kerangka regulasi yang difokuskan pada penetapan status kedaruratan bidang kesehatan masyarakat, yang diatur dalam Keputusan Presiden Nomor 11 tahun 2020.

Kelompok GBKA memiliki kegiatan rutin penimbangan, pemilihan, tabungan sampah dan inovasi pengelolaan sampah. Keanggotaan dari bank sampah di Kelompok GBKA sebagian besar merupakan ibu rumah tangga dan ibuibu berusia lanjut. Kondisi sosial budaya masyarakat setempat terutama ibu-ibu, aktif mengikuti kegiatan-kegiatan seperti Pemberdayaan Kesejahteraan Keluarga (PKK) dan rangkaian kegiatan lainnya. Meskipun begitu mereka tidak terbiasa dengan aktivitas berbasis digital. Hal tersebut merupakan salah satu bentuk kerentanan yang diakibatkan oleh kondisi struktural suatu kelompok masyarakat. Struktur sosial budaya masyarakat yang belum mengadopsi digitalisasi serta belum memasuki tahap tersebut, dikarenakan karakteristik kehidupan di desa yang masih sederhana dan masih memiliki ikatan dan interaksi yang kuat antar masyarakat.

Komunikasi berbasis digital atau dalam jaringan (daring) dimanfaatkan sebagai alternatif utama berkomunikasi di masa pandemi COVID-19. Begitu juga dengan pelaksanaan rencana kerja Program Betulungan Beberseh Kampong tahun 2020 terkait dengan peningkatan kapasitas anggota GBKA yang dilakukan melalui pelatihan inovatif dalam pengolahan sampah. Pada masa pandemi COVID-19 ini, seluruh kegiatan pelatihan dan monitoring program oleh PT Pertamina Hulu Mahakam dilaksanakan secara daring. Komunikasi berbasis digital melalui platform seperti WhatsApp bukan merupakan hal yang baru untuk beberapa anggota GBKA. Namun penggunaan platform pertemuan daring seperti Zoom Meeting, Webex, Google Meet belum pernah dimanfaatkan oleh hampir seluruh anggota GBKA.

Kecamatan Anggana secara geografis terbentang di sebuah delta yang memiliki komposisi wilayah unik, yakni wilayah darat, sungai dan laut. Aksesibilitas wilayah ini terbilang cukup sulit dikarenakan kondisi jalan penghubung antara desa di daerah darat yang masih berupa tanah merah, serta minimnya transportasi untuk mengakses wilayah desa laut. Kondisi terpencil tersebut merupakan salah satu faktor penghambat bagi ketiadaannya jaringan internet yang memadai. Hal tersebut merupakan salah satu kerentanan yang dihadapi oleh kelompok GBKA di tengah upaya digitalisasi kegiatan kelompok di tengah pada masa pandemi COVID-19.

Berkaitan dengan tujuan Kelompok GBKA di tengah masyarakat sebagai kelompok sosial yang berupaya memberikan dampak positif terhadap kondisi sosial, ekonomi dan lingkungan anggota melalui kegiatan tabungan sampah. Mekanisme kegiatan tersebut dilakukan melalui pemilahan sampah rumah tangga dan penimbangan sampah anorganik yang sudah dikategorikan berdasar jenisnya untuk kemudian dicatat sebagai tabungan sampah yang dapat diambil dalam bentuk uang pada jangka waktu tertentu. Namun, dalam masa pandemi himbauan untuk mengurangi kegiatan tatap muka tentunya berdampak pada aktivitas keseharian masyarakat termasuk GBKA. Dampak langsung yang dirasakan oleh GBKA adalah terhambatnya aktivitas penimbangan rutin tabungan sampah para anggota. Kondisi tersebut terjadi dikarenakan adanya kekhawatiran dari masing-masing anggota atas kondisi pandemi COVID-19 dan upaya mematuhi himbauan untuk menghindari kegiatan yang melibatkan banyak orang. Berdasarkan hasil wawancara, anggota GBKA mengatakan bahwa pelaksanaan kegiatan penimbangan rutin oleh GBKA sempat terhenti pada bulan Maret hingga April, kemudian mulai dilaksanakan kembali namun terjadi penurunan intensitas hasil timbangan selama masa pandemi dibanding biasanya.

Berdasarkan hasil pengambilan data dan pembahasan ditemukan bahwa kerentanan yang dialami anggota GBKA yaitu; 1) Anggota GBKA merupakan kelompok rentan yakni ibu-ibu rumah tangga dan lansia yang tidak 
mengenal aktivitas berbasis digital ; 2) Anggota GBKA yang berdomisili di wilayah terpencil dengan minimnya akses transportasi dan jaringan internet menghambat upaya digitalisasi kegiatan dan; 3)Terhambatnya aktivitas yang melibatkan banyak orang akibat COVID-19 telah produktivitas GBKA dalam kegiatan tabungan sampah yang sempat terhenti dan mengalami penurunan intensitas hingga saat ini.

Ketiga temuan kerentanan yang dialami anggota GBKA merupakan kondisi yang saling berkaitan. Upaya yang dilakukan untuk menjaga eksistensi kelompok selama pandemi adalah dengan memanfaatkan komunikasi berbasis digital, namun keterbatasan sumber daya manusia menjadi hambatan dalam mengimplementasikan strategi tersebut. Hal tersebut kemudian diantisipasi dengan melakukan sosialisasi cara penggunaan platform Webex dan Zoom Meeting melalui sebuah brosur yang disebarkan melalui WhatsApp group. Sayangnya setelah beberapa kali dilakukannya percobaan untuk mengaplikasikan platform tersebut ditemukan hambatan yang dialami oleh anggota seperti hambatan jejaring internet dan beberapa anggota tidak memiliki smartphone yang memadai untuk penggunaan platform berbasis digital.

Sebagaimana dijelaskan oleh Amartya Sen dalam sebuah penelitian terhadap dampak bencana alam, bahwa ketahanan masyarakat yang mengalami bencana dan tinggal di desa menjadi sangat singkat dan pendek dibandingkan masyarakat yang hidup di kota, karena warga kota sebagian besar menyimpan kekayaannya tidak di satu tempat (Riswan \& Arifika, 2012). Kerentanan dalam temuan ini merupakan kondisi yang disebabkan oleh faktor alami kondisi kehidupan di desa yang pada umumnya belum tersentuh digitalisasi. Walaupun sebenarnya kondisi geografis maupun status administratif tempat masyarakat tinggal baik di desa maupun kota, tidak akan menjadi aktor ketertinggalan dan hambatan apabila pembangunan berlangsung secara merata.

\section{Adaptasi GBKA di Tengah Pandemi COVID-19}

Upaya adaptasi yang dilakukan oleh anggota GBKA merujuk pada temuan kerentanan yang secara garis besar merupakan strategi kelompok untuk mempertahankan eksistensi di tengah pandemi COVID-19. Adanya pembaruan dari pola kegiatan masyarakat yang biasa dilaksanakan

\section{Pelaksanaan Pelatihan Ekobrick}

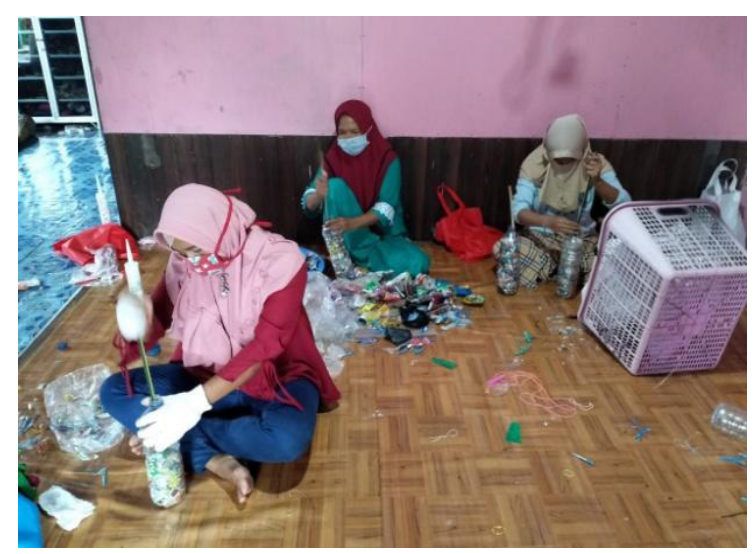

Sumber: Laporan Implementasi Program Betulungan

secara luring kemudian bergeser menjadi daring diakibatkan oleh adanya keterbatasan ruang gerak di tengah pandemi. Hal tersebut merupakan sebuah perubahan struktural secara masif bagi anggota kelompok dengan latar belakang sebagai ibu rumah tangga dan lansia sebagai kelompok masyarakat yang tidak tersentuh digitalisasi.

Adaptasi perilaku selanjutnya adalah kebiasaan baru berupa upaya pencegahan penularan COVID-19 dengan menggunakan masker, cuci tangan dengan sabun secara rutin, menjaga jarak serta menghindari kerumunan. Kebiasaan tersebut sebenarnya relevan dengan program Perilaku Hidup Bersih dan Sehat (PHBS) yang dicanangkan oleh Kementerian Kesehatan (Kemenkes). Di sisi lain, kesadaran masyarakat Kecamatan Anggana terkait dengan PHBS masih harus ditingkatkan. Artinya, penerapan protokol mitigasi COVID-19 menjadi tidak mudah bagi masyarakat yang belum sepenuhnya menerapkan PHBS dalam kehidupan kesehariannya. Oleh karena itu, salah satu upaya yang dilakukan untuk meningkatkan kesadaran masyarakat atas pentingnya menjaga kebersihan terutama dalam kondisi pandemi adalah dengan menyelenggarakan kegiatan Sosialisasi PHBS dan Mitigasi COVID-19 yang dilakukan secara daring.

Disamping melakukan sosialisasi sebagai upaya peningkatan kesadaran masyarakat, kegiatan untuk mendorong penerapan PHBS selanjutnya ialah melalui pelatihan pembuatan tempat cuci tangan dengan bahan dasar jirigen bekas. Tempat cuci tangan sederhana tersebut 
Aldita Cindy Arfidiandra, Riana Rahmaningrum, Wazirul Luthfi - Ketahanan Sosial Berbasis Kelompok Peduli Lingkungan dalam Menghadapi Pandemi COVID-19: Studi pada Gerakan Bersih Kecamatan Anggana

wajib dipasang di setiap pos penimbangan sampah. Hal tersebut dimaksudkan sebagai bentuk pengimplementasian protokol pencegahan penularan COVID-19 yang dibarengi dengan aktivitas yang relevan di GBKA, yakni pemanfaatan barang bekas sebagai upaya pengurangan produksi sampah anorganik. Dengan adanya himbauan untuk memasang tempat cuci tangan hasil kreasi anggota GBKA mampu meningkatkan motivasi mereka dalam menerapkan PHBS secara sukarela.

\section{Gambar 2}

Tempat Cuci Tangan Sederhana

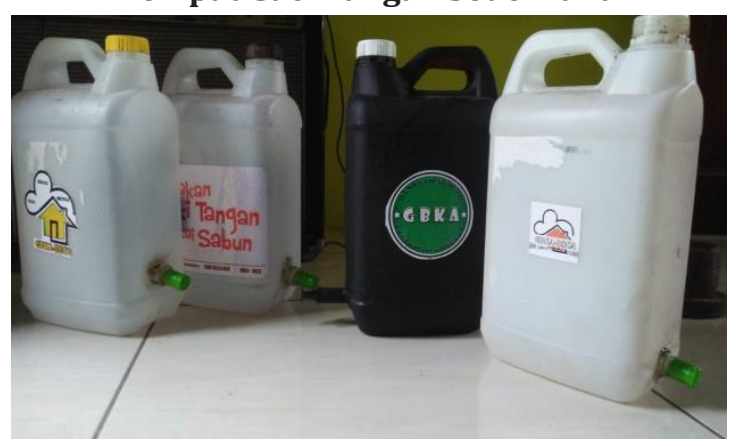

Sumber: Laporan Implementasi Program Betulungan

Adaptasi yang dilakukan tidak berhenti pada penerapan perilaku baru sebagai upaya pencegahan. Selain pencegahan dalam kondisi pandemi ini, masyarakat juga perlu diarahkan dan dibekali kemampuan menuju pemulihan kondisi. Kemampuan yang dimaksud bukan hanya sekedar kemampuan bertahan, tetapi di dalamnya ada unsur dinamik, yaitu kemampuan untuk segera kembali kepada kondisi semula atau bahkan lebih baik lagi (Padmiati, 2013). Pemulihan kondisi ini merupakan sebuah dorongan sekaligus rangsangan agar masyarakat mulai mempersiapkan strategi untuk bangkit dari keterpurukan sosial ekonomi akibat pandemi COVID-19.

Kegiatan GBKA dalam rangka pemulihan kondisi sosial ekonomi di tengah pandemi ini adalah peningkatan kapasitas anggota kelompok melalui inovasi pengolahan sampah anorganik dan ketahanan pangan yang diinisiasi oleh PT Pertamina Hulu Mahakam Lapangan CPU. Kegiatan ini diharapkan dapat mendorong anggota GBKA untuk mampu menyiapkan diri menuju tahap pemulihan secara sosial ekonomi dengan mandiri meskipun pandemi belum usai. Adaptasi dilakukan untuk memampukan anggota GBKA bertahan hidup di tengah perubahan yang membawa mereka ke dalam kondisi yang tidak menguntungkan. Adanya pandemi ini merupakan tantangan bagi seluruh lapisan masyarakat, termasuk anggota GBKA karena tidak ada kondisi yang menjadi lebih baik setelah merebaknya COVID-19. Dengan demikian adaptasi baik dari segi perilaku hidup bersih, kemandirian ekonomi serta ketahanan pangan menjadi kunci untuk tetap bertahan di tengah krisis akibat pandemi ini.

Peningkatan kapasitas untuk menyiapkan anggota GBKA menuju tahap pemulihan dilakukan melalui pelatihan pemanfaatan sampah anorganik menjadi produk kerajinan yakni tas. Harapan kedepan, pelatihan ini dapat memberikan keterampilan bagi para anggota untuk memproduksi tas berbahan dasar plastik bekas yang dapat dijual untuk menambah pendapatan. Peningkatan kapasitas dalam rangka penguatan ketahanan pangan anggota adalah pelatihan budidaya ikan dalam ember dan tanaman hidroponik. Harapan dari adanya penguatan ketahanan pangan ini adalah mengurangi pengeluaran konsumsi dengan menanam dan membudidayakan bahan pangan sehat secara mandiri. Di tengah krisis akibat pandemi dimana sektor ekonomi melemah, masyarakat yang hidup di desa turut merasakan dampaknya. Namun, masyarakat di desa yang berpotensi menjadi kelompok terdampak dapat mengurangi ketergantungannya pada pengalokasian bantuan pemerintah bila memiliki kemampuan ketahanan pangan. Oleh karena itu penguatan ketahanan pangan masyarakat desa penting sebagai upaya untuk untuk mewujudkan kemandirian.

Strategi mempertahankan keberlangsungan kelompok di tengah pandemi dapat dilihat dari kemauan dan usaha para anggota untuk beradaptasi. Dari pembahasan di atas adaptasi perilaku baru yang dilakukan anggota GBKA untuk mempertahankan eksistensi kelompok menunjukkan kelompok sosial memiliki kapasitas beradaptasi dalam mengatasi kerentanan di tengah pandemi. Dijelaskan bahwa kapasitas adaptasi merupakan penyesuaian dalam jangka panjang, sedangkan respons adaptasi adalah coping behaviour atau perilaku penyesuaian dalam jangka pendek (Gallopin, 2006). Digitalisasi merupakan sebuah perubahan struktural dan secara tidak langsung memaksa anggota kelompok GBKA mulai mempelajari dan 
mempraktekkan secara bertahap komunikasi digital yang diawali dengan melalui pelatihan yang dilakukan secara daring. Dengan demikian upaya tersebut dapat dikategorikan sebuah penyesuaian jangka panjang bagi anggota GBKA. Adanya pola kebiasaan baru dalam konteks digitalisasi ini dapat diaplikasikan dalam kegiatan lainnya, baik pemasaran produk, penyebaran wawasan dan manfaat lain bagi penggunanya.

Gambar 3

\section{Panduan Mengoperasikan Aplikasi Zoom}

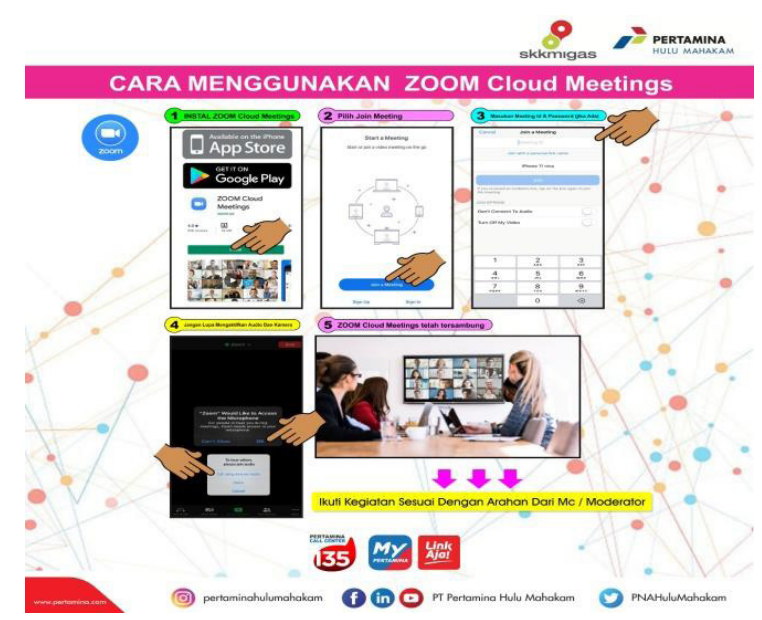

Sumber: Laporan Implementasi Program Betulungan

\section{Diskusi}

Ketahanan sosial menggambarkan kemampuan masyarakat untuk bertahan dari kerentanan. Kemampuan yang dimaksud bukan hanya sekedar kemampuan bertahan, tetapi di dalamnya ada unsur dinamik, yaitu kemampuan untuk segera kembali kepada kondisi semula atau bahkan lebih baik lagi (Padmiati, 2013). Berdasarkan definisi tersebut, maka dinamika yang terjadi di dalam kelompok merupakan sebuah proses adaptasi GBKA dalam rangka mempertahankan keberlangsungan kelompok. Dikatakan bahwa ketahanan sosial mengandung arti kemampuan untuk mengubah ancaman dan tantangan menjadi peluang dan kesempatan (Nuryana, 2002).

Dinamika kelompok GBKA dalam menghadapi pandemi COVID-19 sebenarnya merupakan proses beradaptasi terhadap perilaku yang baru, yakni tahap pencegahan melalui penerapan PHBS, pelaksanaan kegiatan berbasis digital, hingga rangkaian kegiatan dalam rangka peningkatan kapasitas bagi anggota sebagai bekal menuju tahap pemulihan di tengah krisis pandemi. Bahwa terhambatnya kegiatan yang mengancam terhentinya aktivitas kelompok dapat dihadapi dengan upaya penyesuaian perilaku yang baru.

Ketahanan sosial masyarakat dapat dipandang sebagai sebuah konsep yang memiliki dua dimensi makna, yaitu ketahanan sosial dalam pengertian alat atau metode, dan ketahanan sosial dalam pengertian tujuan (Padmiati, 2013). Ketahanan sosial masyarakat sebagai metode atau alat, merupakan suatu rumusan dan model pendekatan ketahanan sosial yang dapat memberikan berbagai input dan output bagi upaya terciptanya suatu kondisi masyarakat yang berkemampuan memenuhi kebutuhankebutuhannya, serta masyarakat yang memiliki suatu daya tahan dalam mengatasi permasalahanpermasalahan sosial yang dihadapi (Zuhri, 2002). Sedangkan ketahanan sosial sebagai tujuan (goal) merupakan harapan-harapan ideal yang dapat diwujudkan dengan menggunakan cara atau metode, sehingga masyarakat menjadi dinamis, berkemampuan, memiliki daya tahan, memiliki daya juang dalam memenuhi kebutuhan kebutuhannya, dan menghadapi berbagai tantangan dan permasalahan sosial, baik secara individu, keluarga, kelompok, maupun masyarakat (Zuhri, 2002)

Berdasarkan definisi tersebut, ketahanan sosial GBKA di tengah pandemi COVID-19 merupakan sebuah harapan ideal yang diwujudkan dengan suatu cara, yakni dinamika kelompok dalam beradaptasi dengan adanya perubahan akibat pandemi COVID-19. Harapan ideal yang ingin dicapai oleh GBKA adalah mempertahankan eksistensi kelompok serta kemandirian anggota di tengah pandemi dengan segala penyesuaian dengan pola yang baru. Setiap kelompok masyarakat memiliki cara tersendiri dalam menghadapi perubahan sesuai dengan karakteristik dan kondisi sosial budayanya. Hal yang sudah diterapkan dan menjadi bagian dari norma suatu kelompok masyarakat bisa menjadi sesuatu perubahan yang baru bagi kelompok masyarakat lainnya. Dalam konteks penelitian ini hambatan dan kerentanan yang dialami oleh anggota GBKA memunculkan strategi baru yang semestinya dilakukan untuk dapat mencapai kondisi ideal yang diharapkan. Upaya penyesuaian anggota GBKA tidak dapat dipisahkan dari kuatnya potensi modal sosial yang mereka miliki. 
Aldita Cindy Arfidiandra, Riana Rahmaningrum, Wazirul Luthfi - Ketahanan Sosial Berbasis Kelompok Peduli Lingkungan dalam Menghadapi Pandemi COVID-19: Studi pada Gerakan Bersih Kecamatan Anggana

Konsep ketahanan sosial masyarakat dapat ditinjau dalam perspektif luas dan sempit. Ketahanan sosial dalam pengertian luas yakni bagian integral dari ketahanan nasional seperti halnya ketahanan ekonomi, politik, budaya, dan pertahanan keamanan yang merupakan unsur pembentuk ketahanan nasional, sedangkan ketahanan sosial dalam arti sempit dipandang sebagai kemampuan komunitas dalam mengatasi resiko akibat perubahan sosial, ekonomi, dan politik (Betke, 2002). Dari konsep di atas, ketahanan sosial kelompok GBKA merupakan upaya penguatan kelompok pada level komunitas lokal yang merupakan bagian dari unsur penguat ketahanan nasional. Penguatan kelompok merupakan integrasi dari penguatan individu di dalamnya, begitu juga ketahanan nasional yang diwujudkan melalui penguatan keseluruhan aspek kehidupan individu, keluarga, kelompok dan masyarakat yang dinaungi.

Upaya perlindungan kepada anggota dilakukan dengan adanya penyesuaian pada pola kebiasaan yang baru untuk mempertahankan eksistensi kelompok di tengah pandemi COVID-19. Upaya pencegahan disfungsi GBKA sebagai kelompok yang berupaya untuk meningkatkan perekonomian anggotanya dapat dilakukan melalui penyesuaian baru. Penyesuaian tersebut dilakukan agar aktivitas kelompok tetap berjalan sebagai salah satu upaya mewujudkan kemandirian ekonomi. Adanya investasi sosial dalam interaksi yang terjalin diwujudkan dengan kegiatan penimbangan sampah yang-memiliki dampak positif pada perekonomian serta perbaikan lingkungan. Secara tidak langsung kegiatan GBKA telah mengurangi pencemaran lingkungan akibat sampah anorganik melalui dengan membiasakan menabung. Dampak dari kegiatan tersebut adalah terwujudnya lingkungan bersih dan lestari serta peningkatan pendapatan bagi anggota yang merupakan sebuah investasi yang menguntungkan dari adanya jaringan di dalam kelompok. Selanjutnya, GBKA melakukan pengelolaan hambatan dan potensi yang dimiliki oleh anggota mengembangkan kapasitas dan keterampilan anggota sebagai bekal kemandirian ekonomi serta penguatan ketahanan pangan sebagai upaya pencegahan dari terjadinya konflik akibat krisis di tengah pandemi yang berkepanjangan.

Berdasarkan hasil di atas dalam memahami ketahanan sosial GBKA dari berbagai sudut pandang berbagai konsep, maka diketahui bahwa ketahanan sosial GBKA di tengah pandemi COVID-19 dilandasi oleh adanya kemauan dan usaha dari masing-masing anggota untuk mempertahankan keberlangsungan kelompok dengan cara menerima adanya perubahan yang dilakukan melalui proses adaptasi. Kemauan dan usaha dari masing-masing individu di dalam kelompok merupakan wujud nyata dari kuatnya unsur modal sosial yang dimiliki masyarakat tersebut. Pemahaman di atas mengindikasikan bahwa ketahanan sosial masyarakat dapat diwujudkan dan diupayakan menjadi kuat, jika individu, keluarga, kelompok, masyarakat, dan juga lembaga sosial dapat menjalankan fungsi-fungsi sosialnya dengan baik di dalam pencapaian tujuan-tujuannya (Padmiati, 2013).

Ketahanan sosial tidak dapat dipisahkan dari keberadaan modal sosial masyarakat. Unsur modal sosial yakni norma, kepercayaan dan jaringan dalam kerangka ketahanan sosial memiliki arti dan fungsi yang strategis dalam mewujudkan suatu tatanan sosial yang teratur serta harmonis (Zuhri, 2002). Keberfungsian modal sosial di dalam masyarakat berpengaruh signifikan terhadap ketahanan sosial masyarakat. Dikatakan bahwa bentuk konkrit dari modal sosial adalah kelompok sosial yang dibentuk oleh komunitas atau masyarakat itu sendiri (Padmiati, 2013). Bentuk konkrit dari fungsi modal sosial di dalam kelompok GBKA adalah nilai "betulungan" atau nilai saling tolong menolong sebagai nilai dan norma yang hidup di dalam masyarakat.

Dijelaskan bahwa lembaga sosial di tengah masyarakat yang berperan sebagai media masyarakat untuk mendorong dan memfasilitasi tindakan masyarakat guna mencapai tujuan kolektif sangat penting. Seperti halnya GBKA merupakan wadah bagi anggotanya secara kolektif melakukan upaya pengurangan pencemaran lingkungan akibat sampah, sekaligus mendapatkan nilai ekonomis di dalam kegiatan mereka. Adanya tindakan kolektif untuk mencapai tujuan mereka merupakan keberfungsian modal sosial yang difasilitasi oleh lembaga sosial. Seperti halnya dikutip dari definisi social capital atau modal sosial secara sederhana bahwa yakni norma-norma dan jaringan-jaringan kerja yang membuat orang bertindak secara kolektif (Nuryana, 2002).

Ketahanan sosial kelompok GBKA tampak dari dinamika kelompok dalam menghadapi 
perubahan dan melakukan penyesuaian terhadap pola kebiasaan baru. Di tengah maraknya ketidakberfungsian lembaga akibat ketidakmampuan anggota dalam melakukan penyesuaian, sebaliknya GBKA menunjukkan kemampuan lembaga sosial dalam menghadapi hambatan pengimplementasian kegiatan di tengah pandemi COVID-19 ini. Keberhasilan tersebut dilakukan melalui prakarsa dan perilaku saling membantu dari anggota untuk menyesuaikan diri dengan perubahan yang mendorong GBKA tetap bertahan hingga hari ini. Hal tersebut merupakan bukti bahwa fungsi ikatan di dalam unsur modal sosial dan mengapa sasaran dari pengembangan ketahanan sosial diarahkan pada lembaga sosial itu nyata. Bahwa di dalam lembaga sosial terdapat sejumlah nilai dan norma sosial yang dihayati dan diamalkan bersama, sebagai upaya mewujudkan kerukunan dan kebersamaan antar lapisan masyarakat (Padmiati, 2013).

\section{Kesimpulan}

Dalam penelitian ini ditemukan, bahwa proses adaptasi anggota kelompok merupakan strategi bagi kelompok untuk tetap eksis di tengah kondisi pandemi. Penyesuaian perilaku baru yang dilakukan anggota merupakan upaya untuk mengurangi kerentanan mereka. Sebagai contoh, latar belakang anggota GBKA yang merupakan ibu rumah tangga yang gagap teknologi dengan keterbatasan ruang gerak di masa COVID-19, secara bertahap mulai belajar untuk mampu mengikuti pelatihan secara daring. Namun ada kerentanan yang memang tidak bisa diubah dengan adanya penyesuaian baru yakni keterpencilan dan akses terhadap fasilitas publik yang tidak memadai. Kerentanan tersebut hanya bisa diantisipasi dengan usaha dari anggota itu sendiri untuk tidak tertinggal dengan adanya perubahan. Tidak tersedianya jaringan yang memadai maka anggota GBKA berusaha mencari tempat-tempat khusus di desa yang memiliki ketersediaan jaringan. Bagi anggota yang tidak memiliki smartphone mumpuni untuk mengikuti pelatihan daring, maka anggota lain yang bertempat tinggal di dekatnya akan memberi pertolongan. Dengan demikian ketahanan sosial GBKA merupakan penguatan kelompok dari adanya kemauan dan prakarsa para anggota yang bersedia untuk menyesuaikan diri dengan perubahan demi mempertahankan eksistensi kelompoknya di tengah pandemi.
Konseptualisasi aktivitas yang dilakukan oleh anggota GBKA adalah nilai "betulungan" yang berarti saling membantu, saling menolong antar manusia sebagai nilai dan karakter telah tumbuh di dalam masyarakat Kecamatan Anggana. Saling menolong menjadi hal yang dominan dalam mendorong proses adaptasi anggota GBKA. Anggota yang memiliki akses terhadap fasilitas penunjang membantu anggota lain yang tidak memiliki. Anggota yang telah mampu mengaplikasikan platform digital membantu menyebarkan informasi kepada anggota yang tertinggal. Konsep saling tolong dan bantu merupakan nilai yang kental dalam proses beradaptasi di dalam kelompok. Dilihat dari swadaya dan prakarsa para anggota saling menopang hambatan anggota satu sama lain.

Karakter "Betulungan" ini tidak terlepas dari kuatnya unsur modal sosial yang telah dimiliki masyarakat. Ketahanan sosial tidak terlepas dari status modal sosial masyarakat itu sendiri. Kuatnya unsur modal sosial seperti jaringan, kepercayaan dan ketersalingan sekaligus merupakan faktor penguat kelompok. Masyarakat yang telah hidup dengan nilai-nilai gotong royong dan guyub rukun, kemudian membentuk kelompok yang mengakomodir tujuan mereka, tentu akan menumbuhkan solidaritas yang membentuk ketahanan sosial kelompok tersebut.

Dengan demikian hasil dari penelitian ini menunjukkan bahwa ketahanan sosial GBKA merupakan harapan kondisi ideal yang diwujudkan dengan berbagai upaya anggota dan dinamika kelompok dalam mempertahankan keberlangsungan kelompok di tengah pandemi COVID-19. Upaya untuk mewujudkan ketahanan sosial GBKA dilakukan melalui adaptasi terhadap pola aktivitas baru yang berbasis nilai kearifan lokal dan modal sosial guna mendorong tindakan bersama untuk mempertahankan keberlangsungan kelompok.

\section{Referensi}

Arifika, Diah dan Armawi, Armaidy. (2012). Kajian Dampak Bencana Lahar Dingin Pasca Letusan Gunungapi Merapi terhadap Ketahanan Sosial Ekonomi. Jurnal Ketahanan Nasional XVII(1), pp. 43-59.

Blaikie, P. (2002). Vulnerability and Disaster in $V$ Desai and R Poter edition 9 The Companion to Development Studies. London: Arnold. 
Aldita Cindy Arfidiandra, Riana Rahmaningrum, Wazirul Luthfi - Ketahanan Sosial Berbasis Kelompok Peduli Lingkungan dalam Menghadapi Pandemi COVID-19: Studi pada Gerakan Bersih Kecamatan Anggana

Betke, Friedhelm. (2002). Statistik Ketahanan Sosial: Menuju Operasionalisasi Konsep Baru dalam Bidang Statistik Sosial dalam Makalah Diskusi Pakar tentang Membangun Konsepsi dan Strategi Ketahanan Sosial Masyarakat. Jakarta: Pusbangtansosmas.

Gallopin, G. C. (2006). Lingkage between Vulnarebality, Recilience, and Adaptive Capacity. Jurnal Global Environmental Change, 16(3), pp.293-303.

Kodoatie, Robert J, dan Roestam, Syarif. (2006). Pengelolaan Bencana Terpadu. Jakarta: Watampone.

McCarthy, E. J. dan Perreault, W. D., (2006). Essentials of Marketing: A Global-Managerial Approach. New York: McGraw-Hill.

Mu'man Nuryana, (2002). Membangun Konsepsidan Strategi Ketahanan Sosial Masyarakat. Jakarta: Pusbangtansosmas.

Padmiati, Etty. (2013). Menuju Masyarakat Berketahanan Sosial melalui Pemberdayaan Lembaga Sosial Lokal di Provinsi Kalimantan Tengah. Jurnal PKS, 12(3), pp. 263-275.
Riswan, Yulianingsih dan Arifika, Diah. (2012). Perempuan dan Bencana: Memberdayakan Potensi Sosial dan Ekonomi Korban Banjir Lahar Dingin Merapi. Jurnal KAWISTARA, 2(2), pp. 165-177.

Sugiyanto, (2002). Lembaga Sosial. Yogyakarta: Global Pustaka Utama.

Suprayoga, Hadi. (2020). Pengurangan Risiko Pandemi COVID-19 Secara Partisipatif: Suatu Tinjauan Ketahanan Nasional terhadap Bencana. The Indonesian Journal of Development Planning, IV(2), pp. 105-224.

Wahyono, Ary. (2016). Ketahanan Sosial Nelayan: Upaya Merumuskan Indikator Kerentanan (Vulnerability) Terkait dengan Bencana Perubahan Iklim.Jurnal Masyarakat Indonesia, 42(2), pp. 185-199.

Zuhri, Bahri, dkk. (2002). Jaringan Strategis Pranata Sosial. Pengembangan Pola dan Penguatan Ketahanan Sosial. Jakarta: Pusbangtansosmas. 